\title{
INFLUENCE OF MILKING ROBOT APPLICATION ON COW LONGEVITY AND AMOUNT OF SOMATIC CELLS IN MILK
}

\author{
Maris Mangalis, Juris Priekulis, Armins Laurs \\ Latvia University of Life Sciences and Technologies, Latvia \\ maris.mangalis@1lu.lv, juris.priekulis@1lu.lv, armins.laurs@promedia.lv
}

\begin{abstract}
The research has been performed in the teaching and research farm, where a part of cows were milked with two milking robots VMS produced by the company De Laval, but other cows - in a separate parlour with side by side $2 \times 10$ type milking equipment. For the research, animals that were not rejected due to traumatism or any specific disease were selected. The information on the length of the productive life of the cows was obtained from the management system of the farm and the Latvian Data Centre In the study, we used data from the Latvian Data Centre (LDC) for 173 Holstein black and white (HM) and 391 Latvian brown (LB) cows.the quality of the obtained milk was evaluated according to the number of somatic cells in it that was determined in the result of laboratory analyses. In the research it was stated that for the cows milked with robots the length of the productive life increases by approximately half year. In turn, evaluating according to the amount of somatic cells, it was stated that the obtained milk complies with the requirements of the normative standards. Nevertheless, it cannot be unequivocally ascertained that using milking robots the quality of milk is always higher than using the side-by-side type milking equipment.
\end{abstract}

Keywords: automatic milking, health, lactation, milk quality.

\section{Introduction}

The first milking robots or AMS were introduced in Latvia in 2007, but at present their total number has reached one and a half hundred [1]. Besides, the speed of their introduction has increased during the recent years. It was promoted by several advantages of robot application.

- The cows usually go for milking willingly, including the night hours, therefore, milking usually does not create stress situations for the animals [2;3].

- The cows visit AMS in average 2.6 to 2.8 times per day. It is promoted not only by the need for milk yield, but also by feeding concentrated feed during milking. Therefore, according to the data of different researchers [2-4], transition to robotised milking increases the milk yield by $5-10 \%$.

- The quality of the obtained milk is higher, as after milking every cow the milking clusters are washed or disinfected by steam. Besides, they are rinsed also, if they accidentally fall off during milking, and only after that they are repeatedly attached to the corresponding teats. Also, at least two times per day the milking equipment milk lines are washed and disinfected [5].

- Improvement of the milk quality is promoted also by its immediate evaluation, as milk from every quarter of the udder flows along a separate line through corresponding sensors. If the milk quality corresponds to the requirements, it flows to a separate container and it is used according to the needs of the farm, for instance, for feeding calves.

- All information of the cow herd, including animal feeding, as well as the amount and quality of the obtained milk, is registered in the management system. Therefore, it makes it easier to control the health of the cows and also the work of the animal breeders becomes easier.

- Considering the above mentioned, it can be prognosticated that application of milking robots can increase the longevity of the animal productive life, as well as the quality of the obtained milk.

- According to the research data in Latvia [6;7], at present the average longevity of cows is 2.53.5 lactations. Nevertheless, it has been found [8] that it is economically profitable to increase this indication, as the highest level of milk yield is reached starting with the third lactation and it continues till the sixth lactation. Besides, for the cows of later lactations also the proportional amount of fat and proteins increases. It should be also considered that a cow can be used for obtaining of milk only after the age of two years, but before that the future milk cows should be bred and taken care of. 
The quality of the obtained milk is also important. In Latvia it is determined by the Regulations No. 345 of the Cabinet of Ministers "Hygiene and minimum safety requirements for small circulation of raw cow's milk" [9]. These regulations mention the most important milk quality indicators, including the number of somatic cells (SCC). According to the existing requirements, this indicator must not exceed 400 thousand cells in one millilitre of milk. Previous research by other scientists $[6 ; 10 ; 11]$ shows that using milking robots, in comparison to milking in the parlour, the amount of the somatic cells is by $20-25 \%$ less. Therefore, the aim of our research was to clarify the positive influence of milking robot application on longevity of the productive life of the herd, as well as on the quality of the obtained milk.

\section{Materials and methods}

The research was performed in the training and research farm, where a part of cows were milked with two milking robots VMS produced by the company De Laval, but other cows - in a separate parlour with side by side $2 \times 10$ type milking equipment. Besides, all cows were kept in high boxes and fed with feed mixture (TMR) at the feeding table. Therefore, the cow handling conditions did not practically differ.

The research was performed in two stages. The first stage was in the period of time from 2014 to 2016, the second - from 2018 to 2020. In both stages of the research the data on longevity of the cow productive life till their exclusion from the herd and the amount of somatic cells determined in laboratory analyses in milk of the cows were summarised and analysed.

For the research, animals that are not excluded due to traumatism or any specific disease were selected. Altogether 564 animals were chosen for the research, including 124 cows that are milked with AMS and 440 cows that are milked with the side-by-side $2 \times 10$ type equipment. The information on the longevity of the cow productive life and the amount of somatic cells in their milk was obtained from the data of the management system and the Latvian Agricultural Data Centre [12]. Data on the amount of SCC in milk was monitored once a year.For processing of the data MS Excel data processing programme Descriptive Statistics was used [13].

For characterisation of the cow longevity, the average weighted number of lactations was used. For its calculation the following formula was used.

$$
V=\frac{\sum_{i=1}^{n} L_{i} \cdot Z_{g i}}{\sum Z_{g}}-0.5,
$$

where $V$-average weighted number of lactations in a cow's life;

$L$ - lactation order, i.e. the first, second or $n$-th lactation;

$Z_{g}-$ number of cows in the first, second and $n$-th lactation;

$n$ - maximal number of lactations;

0.5 - number that evaluates the average cow age of exclusion during the last lactation.

Also, the proportional number of the cows excluded in every lactation was determined. It was stated separately for the cows milked in the parlour and the cows milked with AMS.

$$
B_{i}=\frac{Z_{g 1 i}+Z_{g 2 i}}{\sum Z_{g}} \cdot 100,
$$

where $B_{i}$ - number of cows rejected in $i$-th lactation;

$Z_{g 1 i}$ and $Z_{g 2 i}$ - number of cows excluded in the first and second stages of the research in $i$-th lactation.

In turn, for evaluation of variations of the number of somatic cells (SCC), the average number of cells determined in the laboratory analyses and the standard error (means $\pm \mathrm{SE}$ ) calculated by the computer software were used. 


\section{Results and discussion}

The information on the cows liquidated in both research stages is summarised in Table 1. The table shows that the maximal length of the cow productive life that was determined within the frame of the research is 10 lactations, but the average weighted exclusion age is from 2.41 to 3.17 lactations. Besides, in both stages of the research the determined longevity of the cow productive life is longer, if the cows are milked with AMS. The difference of the cow productive life stated in the first stage of the research is 0.51 lactations, but in the second stage -0.15 lactations. It should be mentioned that these indicators obtained in the result of the research are of orienting character, as such additional indicators as milk yield and cow breeds were not taken into consideration.

Table 1

\section{Number of excluded cows in the research stages}

\begin{tabular}{|c|c|c|c|c|}
\hline \multirow{2}{*}{ Indicators } & \multicolumn{2}{|c|}{ First research stage } & \multicolumn{2}{c|}{ Second research stage } \\
\cline { 2 - 5 } & $\begin{array}{c}\text { Milking with } \\
\text { AMS }\end{array}$ & $\begin{array}{c}\text { Milking in } \\
\text { parlour }\end{array}$ & $\begin{array}{c}\text { Milking with } \\
\text { AMS }\end{array}$ & $\begin{array}{c}\text { Milking in } \\
\text { parlour }\end{array}$ \\
\hline Lactation 1 & 31 & 72 & 26 & 80 \\
\hline Lactation 2 & 24 & 59 & 24 & 84 \\
\hline Lactation 3 & 20 & 48 & 26 & 95 \\
\hline Lactation 4 & 21 & 76 & 17 & 63 \\
\hline Lactation 5 & 15 & 42 & 10 & 31 \\
\hline Lactation 6 & 15 & 18 & 5 & 11 \\
\hline Lactation 7 & 14 & 5 & 3 & 8 \\
\hline Lactation 8 & 2 & 3 & 0 & 4 \\
\hline Lactation 9 & 0 & 0 & 2 & 0 \\
\hline Lactation 10 & 3 & 1 & 1 & 1 \\
\hline$\Sigma Z_{g}$ & 145 & 324 & 114 & 377 \\
\hline$V$ & 3.17 & 2.66 & 2.56 & 2.41 \\
\hline
\end{tabular}

Summary of excluded cows according to lactations is shown in Fig. 1.

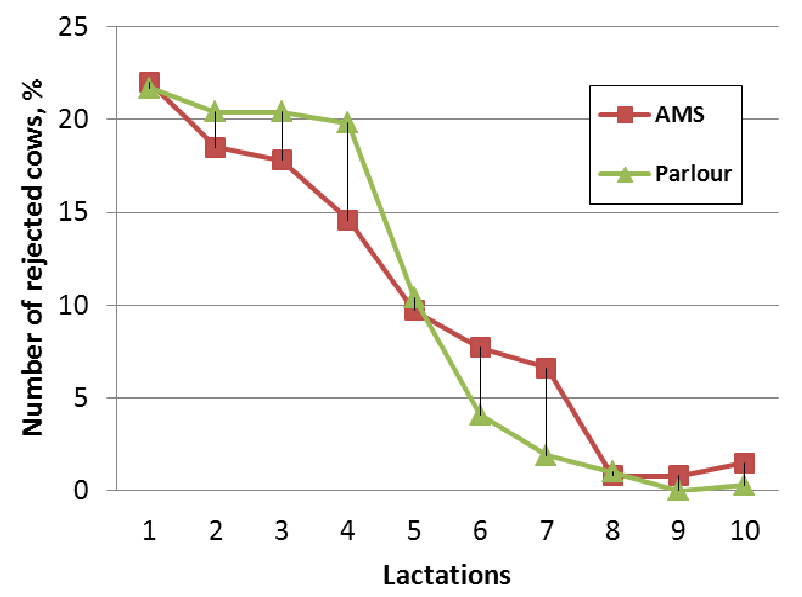

Fig. 1. Proportion of excluded cows in separate lactations

Figure 1 shows that the largest number of cows is excluded during the first four lactations, when the exclusion percentage reaches 15-23\% per year (according to the total number of excluded cows). After that, this indicator starts decreasing very fast, and after the eights lactation it already approaches zero. It can be explained by the herd improvement measures done during the first lactations, when the cows with different health or other problems were intensively excluded.

Variations of the number of somatic cells (SCC) that were determined in the research are shown in Fig. 2. 


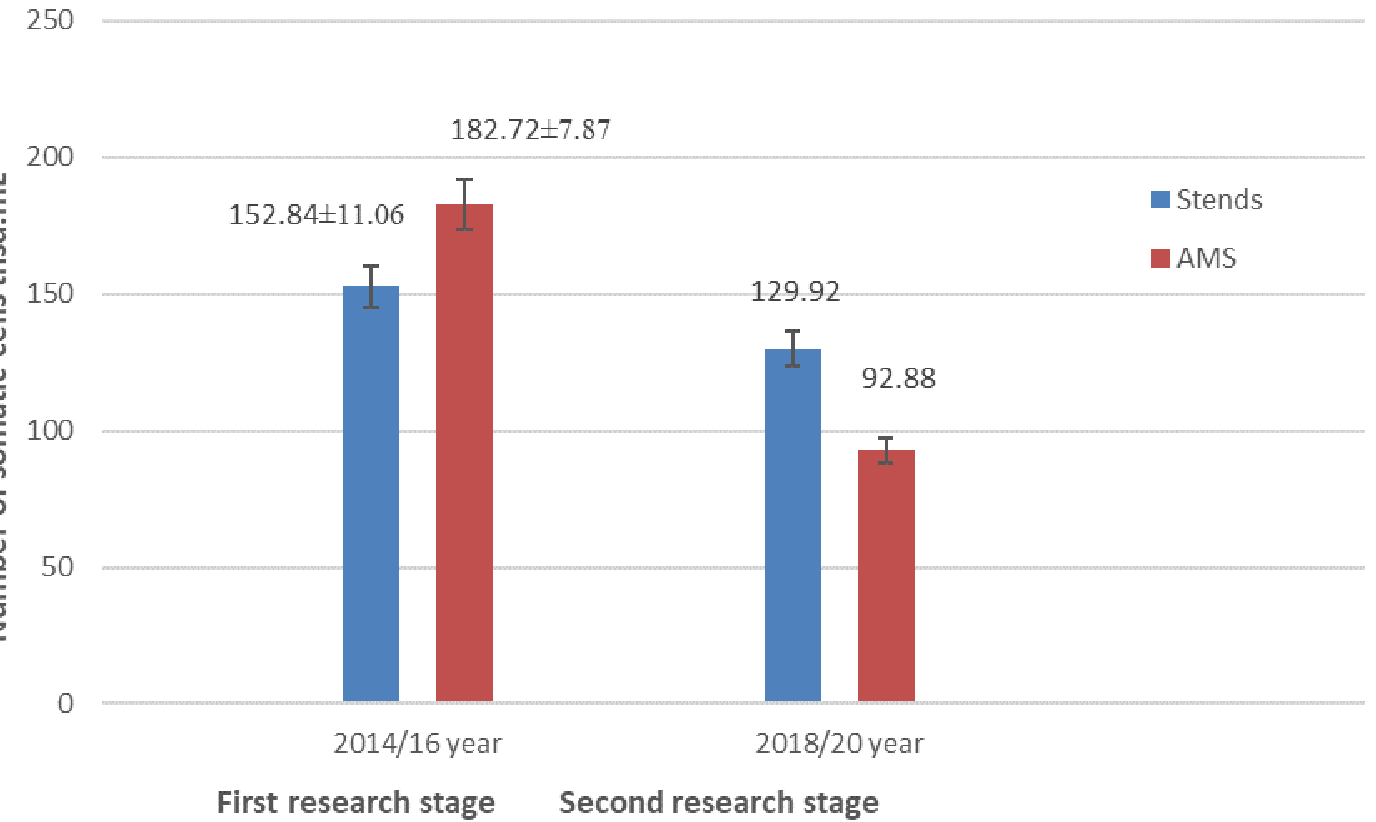

Fig. 2. Number of somatic cells determined in the research

The research results show that in both research stages the number of somatic cells is considerably smaller than the normative amount (400 thousand cells in one millilitre), and according to this indicator the obtained milk is qualitative enough. Still, in the first stage of the research a larger number of somatic cells is stated using AMS, but in the second stage of the research - milking the cows in the parlour with side-by-side milking equipment. This confirms the fact mentioned in scientific literature $[14 ; 15]$ that the number of somatic cells depends not only on the applied milking equipment, but also on many other factors: the age of cows, lactation phase, milk yield etc. Therefore, this indicator cannot serve asanunequivocal criterion for evaluation of the milking equipment.

\section{Conclusions}

1. Using milking robots (AMS), the longevity of the cow productive life increases by approximately 0.5 lactations and it can be prognosticated that it is related to decrease of stress of animals, what is characteristic for this kind of milking. Still, the length of the productive life of separate cows can vary in a wide range.

2. Using milking robots (AMS), the number of somatic cells in the obtained milk does not exceed the normative requirements. Nevertheless, it cannot be unequivocallyascertained that the milk obtained this way will be with less number of somatic cells than using the side-by-side milking equipment.

\section{References}

[1] Priekulis J., Laurs A., Rozentals M., Cinglers K. Profitability of usage of automatic milking systems. In: 17th International Scientific Conference "Engineering for Rural Development" proceedings, LLU, Jelgava, 2018, pp. 250-254.

[2] Svennersten-Sjaunja K.M., Pettersson G. Pros and cons of automatic milking in Europe. Journal of Animal Science, vol. 86, 2008, pp. 37-46.

[3] Klei L.R., Lynch J.M., Barbano D.M., Oltenacu P.A., Lednor A.J., Bandler D.K.Influence of milking three times a day on milk quality. JournalofDairyScience, vol. 8, 1997, pp. 427-436.

[4] Hogeveen H., Ouweltjes W., deKoning, C. J. A. M., Stelwagen. K. Milking interval milk production and milk flow-rate in an automatic milking system. Livestock Production Scienc. vol. 72, 2001, pp.157-167.

[5] Laurs A., Priekulis J., Puriņš M. Studies of Operating Parameters in Milking Robots. In: Proceedings of 8th International Scientific Conference „Engineering for Rural Development”, Jelgava: Latvia University of Agriculture, Faculty of Engineering, 2009, pp. 38-42. 
[6] Jonkus D., Cielava L., Ruska D. Analysis of Dairy Cows Milk Productivity and Quality in the Automatic Milking System. LLU, 2018, 37-40 pp. (InLatvian).

[7] Petrovska S., Jonkus D.Milk Productivity Changes of Different Lactation Dairy Cowin Early Lactation Stage. LLU, 2014, 40-43 pp. (In Latvian).

[8] Cielava L., Jonkus D. Milk Productivity and Quality Depending on Cow Age. LLU, 2016, pp. 1215. (In Latvian).

[9] MK noteikumi Nr. 345 Higiēnas un obligātās nekaitīguma prasības govs svaigpiena apritei nelielā apjomā, spēkā no 13.04.2010. (Regulations of Cabinet of Ministers of Republic of Latvia: Hygiene and minimum safety requirements for the small circulation of raw cow's milk, effective from 13.04.2010). (In Latvian).

[10] Dohmen W., F.Neijenhuis and H. Hogeveen. Relationship between udder health and hygiene on farms with an automatic milking system. Journal of Dairy Science, 93, 2010 pp. 4019-4033.

[11] Klungel G.H., Slaghuis B.A., Hogeveen H. The effect of the introduction of automatic milking on milk quality, Journal of Dairy Science, 83, 2000, 1998-2003.

[12]Piena pārraudzības rezultāti 2016./2017.gadā. (Results of milk monitoring in2016./2017.) [online][25.10.2018.] Available at: http://www.ldc.gov.lv/upload/doc/best_govs_2017.pdf.

[13] Arhipova I., Bāliņa S. Statistics in Economics. R. Datorzinību Centrs. 2003, 351 p. (In Latvian).

[14] Sharma N., Singh N.K., Bhadwal M.S. Relationship of somatic cell count and mastitis: An overview. Asian-Australasian Journal of Animal Sciences, 24(3), 2011, pp. 429-438.

[15] Yoon, J.T., Lee, J.H., Kim, C.K., Chung, Y.C., Kim, C.H. Effects of milk production, season, parity and lactation period on variations of milk urea nitrogen concentration and milk components of Holstein dairy cows. Asian-Australasian Journal of Animal Sciences, 17(4), 2004, pp. 479-484. 